\title{
Pedagogical Reflection to Improve Professionalism of Islamic Education Teacher (GPAI) at Junior High School (SMP) Level through Applicable Design of Educational Curriculum and Professional Teacher Training (PLPG) in 2013
}

\author{
Taufiqurrahman \\ Department of Islamic Education, Faculty of Education and Teacher Training IAIN North Sumatra \\ E-mail: taufiqurrahman@yahoo.co.id \\ Nurhidayah \\ Department of Islamic Education, Faculty of Education and Teacher Training IAIN North Sumatra \\ E-mail: nurhidayah1163@yahoo.com \\ Amiruddin Siahaan \\ Department of Islamic Education, Faculty of Education and Teacher Training IAIN North Sumatra \\ E-mail: siahaanamiruddin@gmail.com \\ DOI: http://dx.doi.org/10.15548/it.v22i1.119
}

\begin{abstract}
Abstrac
Educational curriculum and teacher certification training (PLPG) is structured to ensure that participants are able to absorb learning materials and carry out its function as educators, teachers, counselors, and coaches. PLPG is a tool that allows teachers to carry out its functions effectively so that the wider implications for the learning process. Through the curriculum of teacher professionalism is pursued inherent in life and the life of the teacher. Professionalism attached to it can be seen from the reflection that they appear in everyday life in a pedagogical context, personality, professional, and social.
\end{abstract}

Key Words: Pedagogical, Reflection, Professional Teacher, Educational Curriculum

\section{INTRODUCTION}

This study is initiated to improve the quality of Indonesian human resources as a manifestation of one of the nation's national vision, which is to educate the nation, then sought a formula that is both effective and rational to improve the quality of teachers as the frontline in achieving the national vision. The intellectual life of the nation is the duty of the government which is got the mandate of the Indonesian people.

The mandate that is given to the government is to educate the nation. Therefore, it must be done systematically through institution that has authority in increasing Indonesian's intelligence that is institution or educational institution.
If we talk about educational unit as an institution that has authority in increasing intelligence, teacher serves as the most responsible person in conducting teaching and learning process in the classroom. A teacher then has to be able to perform his profession either as educator, teacher, mentor or coach. The teacher's tasks of course have provisions to carry out the tasks of education. He/she must do things that allow the entire task to essentially run by referring to the regulations related to the duties and obligations attached to it. All obligations and responsibilities should be carried out in accordance with the provisions of the binding before, so he has a chance to be able to devote him based on guidelines set by various regulations. This is what will make the teacher can work based on the standard provisions. 
Efforts are being made to improve the effectiveness of teachers obligations through certification. Certification is meant here is the process of realizing the Law No. 14 Year 2005 on Teachers and Lecturers. With teacher certification then professional teachers may earns the right as professionals.

Act No. 14 of 2005 on Teachers and Lecturers stated that teachers are professional educators with the primary task of educating, teaching, guiding, directing, training, assessing, and evaluating students on early childhood education, formal education, basic education, and high education. Professional teachers must have a minimum academic qualification undergraduate (S-1) or a diploma four (D-IV), master competencies (pedagogical, professional, social and personality), a certified educator, physically and mentally healthiness, and have the ability to realize the goal of education national.

Recognition position of teachers as professionals is evidenced by a certificate of educators. Furthermore, Act No. 14 of 2005 on Teachers and Lecturers defines that professional is the work or activity conducted by a person and become a source of income that life requires expertise, skills, or skills that meet certain quality standards or norms and require professional education.

As professionals, teachers are expected to improve the dignity and its role as an agent of learning. Teacher certification as an effort to improve teacher quality is expected to improve the quality of learning and the quality of education in Indonesia on an ongoing basis (Book 1 Guidelines for Determination Participant Teacher Certification in 2013, 2012: $1)$.

Empowering teachers to become professionals serves an effort to improve the quality of education as part of efforts to improve the quality of education and learning in the educational unit. Through the certification process, professional teachers will be capable of performing tasks as task demands professionalism.
To improve the quality of the teacher, there is no other way than by the certification done. This certification allows in measuring the activity of professional competence of teachers, because the whole set of certification requires teachers to follow the Professional Teacher Education and Training (PLPG). Through this PLPG every teacher is getting science, knowledge, and skills that enable it to be more competent and professional in carrying out the tasks of education and learning.

This article seeks to uncover the materials that should be given to teachers during the PLPG process. The goal is to ensure that the entire curriculum has been structured as well as demands for increasing professionalism of teachers.

\section{Purpose of education and learning Islam through Islamic religious education teacher competence (GPAI)}

Education and learning Islam is basically related to the knowledge and implementation of that knowledge so that it becomes a habit for students. Learning Islam is not perfect if only taught in the context of purely cognitive. Therefore, the process of education and learning Islam should be oriented to cognitive and affective aspects simultaneously.

Cognitive orientations are based on the principles of this knowledge, followed by affective aspect or behavior as well. If the cognitive and affective aspects of running in the learning process, the students not only know about their religion, but also he will be able to carry out all those teachings as well as possible. This is the main goal of the study of religion in the education unit at the level, type, and any level.

Islamic Education Development Module in Schools issued by the Directorate General of Islamic Religious Education, Directorate of Islamic Education in Schools (2010: 13-14) explains that the purpose of Islamic education subjects in detail are as follows: 
Table 1

The purpose of Islamic education subjects

\begin{tabular}{|c|c|c|}
\hline NO & $\begin{array}{c}\text { Elements } \\
\text { of PAI }\end{array}$ & Purposes \\
\hline 1 & Qur'an & $\begin{array}{l}\text { 1. To increase the love of } \\
\text { learners to the Koran } \\
\text { 2. To equip learners with } \\
\text { the arguments contained } \\
\text { in the Qur'an as guidance } \\
\text { in addressing and facing } \\
\text { life } \\
\text { 3. Increase the absorption } \\
\text { of learners in worship } \\
\text { prayer, by applying the } \\
\text { laws of recitation and } \\
\text { reading the contents of the } \\
\text { content of the letter / } \\
\text { verses in short letters they } \\
\text { read }\end{array}$ \\
\hline 2 & $\begin{array}{l}\text { Aqeedah - } \\
\text { Morals }\end{array}$ & $\begin{array}{l}\text { 1. Develop creed through } \\
\text { the provision, } \\
\text { fertilization, and } \\
\text { development of } \\
\text { knowledge, appreciation, } \\
\text { practice, habituation, as } \\
\text { well as the experience of } \\
\text { learners of Islamic } \\
\text { theology to become a } \\
\text { Muslim man's growing } \\
\text { faith and piety to Allah } \\
\text { SWT } \\
\text { 2. Realizing the Indonesian } \\
\text { human morality and } \\
\text { avoid moral reproach in } \\
\text { everyday life, both in the } \\
\text { lives of individuals and } \\
\text { sosial, as a manifestation } \\
\text { of the teachings and } \\
\text { values of Islamic } \\
\text { theology }\end{array}$ \\
\hline 3 & $\begin{array}{l}\text { Fiqh / } \\
\text { Worship }\end{array}$ & $\begin{array}{l}\text { equip learners in order to: } \\
\text { 1. know and understand the } \\
\text { main points of Islamic } \\
\text { law to regulate the terms } \\
\text { and procedures for } \\
\text { running the human } \\
\text { relationship with God } \\
\text { that is set in the } \\
\text { jurisprudence of worship }\end{array}$ \\
\hline
\end{tabular}

\begin{tabular}{|l|l}
\hline Iistory of & $\begin{array}{l}\text { and man's relationship } \\
\text { with the fellow who } \\
\text { arranged in Fiqh } \\
\text { muamalah, } \\
\text { 2. implement and adopt the } \\
\text { provisions of Islamic law } \\
\text { correctly in performing } \\
\text { worship to God and social } \\
\text { worship. Experiencing is } \\
\text { expected to grow obey in } \\
\text { running Islamic law, } \\
\text { discipline and social } \\
\text { responsibility are high in } \\
\text { personal and social life } \\
\text { students about the } \\
\text { importance of studying } \\
\text { the foundation teachings, } \\
\text { values and norms of Islam } \\
\text { that has been built by the } \\
\text { Prophet in order to } \\
\text { develop the culture and } \\
\text { civilization of Islam } \\
\text { 2. Build awareness of } \\
\text { students about the } \\
\text { importance of time and } \\
\text { place is a process of the } \\
\text { past, present, and future. } \\
\text { 3. Train the critical power } \\
\text { learners to understand the } \\
\text { historical facts correctly } \\
\text { to be based on a scientific } \\
\text { approach. } \\
\text { 4. Growing appreciation of } \\
\text { heritage learners against } \\
\text { Islam as a civilization } \\
\text { evidence of Muslims in } \\
\text { the past. } \\
\text { 5. Develop the ability of } \\
\text { learners to take the } \\
\text { meaning of historical } \\
\text { events (Islam), modeled } \\
\text { figures of achievement, } \\
\text { and associate it with a } \\
\text { social phenomenon, } \\
\text { culture, politics, } \\
\text { economics, science and } \\
\text { art, and others to develop } \\
\text { the culture and } \\
\text { civilization of Islam }\end{array}$ \\
\hline
\end{tabular}


Objectives are detailed enough in order to achieve an understanding of Islam as a religion of learners, taught thoroughly with based on facts, concepts, principle, and procedures as established in the process of education and learning. The importance based on facts, concepts, principles, and this procedure is to improve the understanding and mastery of the teachers that teaching materials closely related to the nature or kind of material of which must be in the know and be taught.

Based on the material objectives and strategies are selected and determined to be seen first, whether it's just the nature of the material facts, concepts, principles or procedures. Likewise, the purposes of the dominant material are in the cognitive, affective or psychomotor. The strategy should look keenly developed the nature and purpose of contents (Amini, 2013: $60)$.

The nature or type of material of which will be taught by teacher to student, is the most important part to achieve the learning objectives. This needs to be understood by teachers because of the achievements of the material being taught teachers are expected to be perfect and complete, up to learners. Although it should be understood by the teacher that the absorption of learners are not the same, but through the right approach to learning, learners will gain proportionally learning experience.

When referring to the material that will be taught by a teacher of Islamic education, the teacher cannot have to pay attention to the scope of the study of Islamic Education. It is worth noting because it has a different emphasis. It can be seen from the Module Development of Islamic Education in Schools issued by the Directorate General of Islamic Religious Education, Directorate of Islamic Education in Schools (2010: 17), namely:
Table 2

Capability Emphasis of PAI

\begin{tabular}{l|l|l}
\hline NO & $\begin{array}{l}\text { ELEMENTS } \\
\text { OF PAI }\end{array}$ & \multicolumn{1}{c}{ CAPABILITY } \\
\hline 1 & Al-Qur'an & $\begin{array}{l}\text { Emphasis on literacy is } \\
\text { good and right, to } \\
\text { understand the meaning } \\
\text { of textual and contextual, } \\
\text { then practice it in } \\
\text { everyday life }\end{array}$ \\
\hline 2 & Akidah & $\begin{array}{l}\text { emphasis on the ability to } \\
\text { understand and maintain } \\
\text { the belief / faith is true } \\
\text { and to live and practice } \\
\text { the values of al-asma al- } \\
\text { Husna }\end{array}$ \\
\hline 3 & Akhlak & $\begin{array}{l}\text { emphasis on habituation } \\
\text { to implement morality } \\
\text { and away from the } \\
\text { glittering despicable } \\
\text { character of everyday life }\end{array}$ \\
\hline 4 & Fiqih & $\begin{array}{l}\text { emphasis on the ability } \\
\text { of how to implement and } \\
\text { muamalah worship the } \\
\text { true and good }\end{array}$ \\
\hline 5 & $\begin{array}{l}\text { emphasis on the ability to } \\
\text { take meaning and } \\
\text { historical event (Islam) } \\
\text { modeled figures of } \\
\text { achievement, and } \\
\text { associate it with a social } \\
\text { phenomenon, culture, } \\
\text { politics, economics, } \\
\text { science and art, and } \\
\text { others to develop the } \\
\text { culture and civilization of } \\
\text { Islam. }\end{array}$ \\
\hline
\end{tabular}

Suppression capability above requires teachers who really qualified. Because of any Islamic education teacher burdened great responsibility in achieving educational goals of Islam. Achievement of the goals of Islamic education is the most important how in order to draw closer to Allah while strengthening the fact that the aim of Islamic education in line with the objectives of Islam in a comprehensive manner. 
Acts as an educator in the view of the Supreme Islamic education, in line with the purpose God sent him to man, namely to enhance character (al-Hadith). Overall it is a concrete explanation, that the objectives of Islamic education in tune with the goal of Islam itself. Accordingly, God also explains also, that in fact the Apostle was the best of role models for you all (Jalaluddin, 2002: 124).

The presence of the Prophet Muhammad as God's messenger is to explain to people as part of an effort to make man able to portray himself as a human being as a whole. That is, humans are required to be able to keep themselves and their environment so as to make the universe a convenient place for life and human life.

Islamic educational goals can be classified into three main objectives, namely, religious, mundane, and science for science. Three goals were integrated into a single destination called the supreme goal of Islamic education, namely the achievement of human perfection. This goal can only be realized with the approach to God and ongoing relationships between the individual and his Creator. This is the basic core of Islamic education morals (Hery Noer Ali and Munzier, 2000: 151).

The process of education in the context of achieving the goals of Islamic education, basically refers to the presence of the Prophet Muhammad as a bearer of revelation. Based on this, the Islamic education emphasizes not only to understand the various fields of science are taught, but to understand the meaning of each science it for human life.

If referring to such assumptions, it is only natural that the whole range of material taught in Islamic education as shown in the two tables above, namely the passage and suppression capability goals, requires Islamic religious education teachers who have the skills to teach the entire teaching materials. Of course this would require a fairly reliable professional competence of every teacher of Islamic education.

Therefore, the professional competences of teachers of Islamic education are crucial to achieve the objectives of Islamic education. Without the Islamic religious education teachers who understand what to teach and how to teach the right way, it will be difficult to achieve the learning objectives of religion completely and thoroughly.

In everyday communication, Islamic Education Teachers (GPAI) usually dubbed "Ustad". This term (in the Middle East) is used to call a professor. This implies that a GPAI required for commitment to professionalism in carrying out their duties. A professional said, when on her inherent high dedication attitude towards his job, attitude and commitment to the quality of the work process, as well as continuous improvement attitude, which is always trying to improve and update the models or the way it works in accordance with the demands of his day, which is based on the awareness high that the task of educating is the task of preparing the next generation that will live in his time in the future (Iskandar, 2003: $63)$.

Dedication, commitment, and continuously make improvements, is the most important part of the job of a professional. Professionalism is evident from a person's ability to do the job well, intact, and sustainable. Professionalism is certainly a spiritual calling in implementing what their main duty.

\section{Curriculum Teacher Education And Professional Training (PIpg) To Strengthen Pedagogical Component Islamic Education Teachers (Gpai) At The Level Of Secondary School (SMP)}

Education is the key in determining the success of the development of a nation. That is why so many of the leaders of the nation or a country who risked his tenure with emphasis on education after being elected government leaders. This they did because the universal consciousness of the importance of education to keep the conservation values of nationality.

There are many examples of clichés about caring leader in education. Tony Blair, 1996, in the first period as the Prime Minister stated three main programs: "Education, Education, and Education". Blair made 
education a center of economic policy making in the future. Also Kevin Rudd, when he was Prime Minister of Australia, 2007, he gave a speech that Australia's future lie in an education revolution. In his paper, "The Australian Economy Needs an Education Revolution," Rudd explains the important relationship between prosperity, long-term productivity growth, and human capital investment through education (Kompas, Saturday, September 13, 2014, p. 6 col. 3).

The importance of education is what must be maintained in the Indonesian national education system in ensuring the survival of the nation. Therefore, changes made in the various elements of education is a logical consequence of understanding the importance of education in understanding the meaning of life and the life of the nation towards a better future.

Therefore, changes in the educational curriculum is done to improve the quality of education, is in order to improve the overall quality of Indonesian human. Besides, of course, is to be able to realize all eight national education standards. The presence of eight national education standards, is an attempt to achieve the goal of national education so through eight national standards, national vision in the field of education in order to achieve the nation's intelligence can be achieved effectively.

To achieve all this, it becomes crucial for teacher certification carried out with due regard to the material given to teachers through certification curriculum implemented through education and professional training of teachers (PLPG). This curriculum will determine the successful achievement of teachers who have professionalism in accordance with the demands of the teaching profession.

If referring to the curriculum of teacher certification in 2013, particularly for Islamic religious education teacher at secondary school level (SMP), it can be said that the curriculum has to accommodate for improving the quality of teachers. Said that because the curriculum provides the opportunity for participants certification through education and professional training of teachers (PLPG) can understand the principles of education and learning in the education unit.

\section{METHOD}

The curriculum provided is PLPG curriculum allows participants to understand what to do when the learning process in the classroom. It can be seen from the material that will be received when PLPG underway. Content that includes obtaining basic understanding of: (1) implement the curriculum in 2013, (2) understand the characteristics of learners and capable of designing, implementing, and evaluating educational learning, (3) has the personality of a solid, stable, mature, wise, authoritative , and noble, (4) master of science, critical assessment and deepening of the content in the context of the school curriculum, (5) is able to communicate and get along with students, colleagues and the community.

Fifth abilities as participants PLPG competencies mastered it, the competency standards (SKL) to be attached to each participant PLPG. With the fifth SKL, expected participants PLPG increasingly have a high awareness to be able to carry out their duties as educators. Where participants PLPG it is they who are given full authority to carry out the function of the teacher as a whole as educators, teachers, mentors, and coaches in each educational unit.

Curriculum materials in 2013 that includes: (1) a policy of teacher professional development, (2) information curriculum 2013, (3) Deepening the subject material and learning strategies with regard curriculum 2013, (4) Classroom Action Research (CAR), (5) development and learning device packaging, (6) Implementation of learning (peer teaching), (7) a written test and practice exams.

All the material above, have goals, indicators, and an outline of the material. Objectives, indicators, and an outline of the material as outlined in the curriculum PLPG in 2013, detailing what should be given the teacher when follow PLPG. Professional development policy matters, has the goal of improving the 
understanding and practice of teacher professional development policies, indicators to be achieved includes: (1) understand the policies of teacher professional development, and (2) the practice of professional ethics. While the outline of the material include: (1) the competence of teachers, (2) assessment of teacher performance, (3) teacher career development, (4) continuing professional development, (5) professional ethics, and (6) educational character.

Material information curriculum in 2013 has the goal of increasing understanding of curriculum development, 2013. The indicator is to understand the concept of curriculum development and implementation, 2013. The outline of the material is: (1) rational curriculum development, (2) the elements of curriculum changes, (3) the structure of the curriculum, and (4) factors supporting the successful implementation of the curriculum.

Depth materials subject material and learning strategies with regard curriculum in 2013, has the goal of increasing mastery of subject material and learning strategies. The indicators are: (1) master the subject material, (2) reduced misconceptions subject material, (3) control of learning strategies with regard curriculum outline 2013. While the material is: (1) the material field of study (including misconceptions), (2 ) instructional strategies, (3) an assessment of video learning model, (4) assessment of learning outcomes (assignments, tests, behavioral observations, portfolios, performance tests), (5) analysis of the structure of the curriculum and syllabus junior (Class VII-IX).

Material class action research (PTK) has the goal of increasing mastery of the concept and application of PTK. The indicators are mastering concepts and can PTK draft proposal. While the outline of the material is: (1) the deepening of PTK material, (2) the exercise to identify problems in the learning process, and (3) the development of the proposal scheme would PTK.

Packaging materials development and learning tools have the goal of improving the ability to develop learning tools. The indicator is the completion of the learning device for at least $2 \mathrm{KD} / \mathrm{RPP}$ each participant in accordance with the curriculum outline 2013. While the material is: lesson plans, teaching materials, worksheets, instructional media, and assessment instruments. Just as an added note to note that the study considers the balance of soft skills and hard skills that include attitudes, knowledge, and skills.

The material of the implementation of learning (peer teaching) aims to improve the ability to implement learning. The indicator is able to implement appropriate learning curriculum outline 2013. While the material is: (1) practical learning, (2) each participant performed two times@1 JP. In addition need to know that one class (30 participants), made 3 groups and executed in parallel. 2nd display a practice exam.

Once all the material, goals, indicators, and outline the material delivered, followed by a written test and practice. Written test aimed at measuring the professional and pedagogical competence. The indicators are measurable professional and pedagogical competence (mastery of the field of study, pedagogy, curriculum, 2013, and the professionalism of teachers). While the practice exams aim is to measure the ability of implementing learning. The indicators are measurable ability to implement learning. The outline of the material is integrated in peer teaching a second look.

\section{RESEARCH FINDINGS}

To ensure that the whole set of curriculum materials PLPG in 2013 a series of materials to ensure the professionalism of teachers in junior high school, and the scheme can be seen in the following explanation. To ensure the curriculum, beginning with PLPG Graduate Competency Standards in 2013, namely:

1. Understand and be able to implement the curriculum junior in 2013.

2. Understand the characteristics of learners and capable of designing, implementing, and evaluating educational learning. 
3. Having a steady personality, stable, mature, wise, dignified, and noble.

4. Mastering scientific, critical study and deepening of the content in the context of the school curriculum.

5. Ability to communicate and get along with students, colleagues and the

6. Community.

Table 3 shows the element of junior high school curriculum, as in the following:

Table 3

Junior High School Curriculum PLPG 2013

\begin{tabular}{|c|c|c|c|c|c|c|}
\hline NO & CONTENT & $\mathbf{T}$ & $\mathbf{P}$ & OBJECTIVE & INDICATORS & OUTLINE \\
\hline A & General & & & & & \\
\hline 1 & $\begin{array}{l}\text { Teacher } \\
\text { Professional } \\
\text { Development } \\
\text { Policy }\end{array}$ & 4 & & $\begin{array}{l}\text { Increase } \\
\text { understanding } \\
\text { and practice of } \\
\text { teacher } \\
\text { professional } \\
\text { development } \\
\text { policies }\end{array}$ & $\begin{array}{l}\text { 1. Understand } \\
\text { the policy of } \\
\text { teacher } \\
\text { professional } \\
\text { development } \\
\text { 2. The practice } \\
\text { of professional } \\
\text { ethics }\end{array}$ & $\begin{array}{l}\text { 1. Competence of teachers } \\
\text { 2. Assessment of teacher } \\
\text { performance } \\
\text { 3. Development of a } \\
\text { teacher's career } \\
\text { 4. Development of } \\
\text { Sustainable Profession } \\
\text { 5. Ethics profession } \\
\text { 6. Education characters } \\
\end{array}$ \\
\hline 2 & $\begin{array}{l}\text { Information } \\
\text { Curriculum } \\
2013\end{array}$ & 4 & & $\begin{array}{l}\text { Increasing } \\
\text { understanding } \\
\text { of curriculum } \\
\text { development } \\
\text { in } 2013\end{array}$ & $\begin{array}{l}\text { Understanding } \\
\text { the concept } \\
\text { development and } \\
\text { implementation } \\
\text { of the curriculum } \\
\text { in } 2013\end{array}$ & $\begin{array}{l}\text { 1. Rational curriculum } \\
\text { development. } \\
\text { 2. Elements of curriculum } \\
\text { change. } \\
\text { 3. Structure of the } \\
\text { curriculum. } \\
\text { 4. Factors supporting the } \\
\text { successful } \\
\text { implementation of the } \\
\text { curriculum. }\end{array}$ \\
\hline $\mathrm{B}$ & Principal & & & & & \\
\hline 1 & $\begin{array}{l}\text { Deepening the } \\
\text { subject } \\
\text { material and } \\
\text { learning } \\
\text { strategies } \\
\text { taking into } \\
\text { hatikan } \\
\text { curriculum } \\
2013\end{array}$ & 30 & & $\begin{array}{l}\text { Improving } \\
\text { mastery of } \\
\text { subject } \\
\text { material and } \\
\text { learning } \\
\text { strategies }\end{array}$ & $\begin{array}{l}\text { 1. Mastering the } \\
\text { subject } \\
\text { material } \\
\text { 2. Reduced } \\
\text { misconceptions } \\
\text { subject material } \\
\text { 3. Mastering } \\
\text { learning } \\
\text { strategies by } \\
\text { taking into } \\
\text { account the } \\
\text { curriculum in } \\
2013\end{array}$ & $\begin{array}{l}\text { 1. Material field of study } \\
\text { (including } \\
\text { misconceptions) } \\
\text { 2. Learning Strategy } \\
\text { 3. Assessment of the } \\
\text { learning model video } \\
\text { 4. Assessment of learning } \\
\text { outcomes (assignments, } \\
\text { tests, pengama tan } \\
\text { behavior, portfolio, test } \\
\text { performance) } \\
\text { 5. Analysis of the structure } \\
\text { of the curriculum and } \\
\text { syllabus junior (Class } \\
\text { VII-IX) }\end{array}$ \\
\hline 2 & Classroom & 2 & 6 & Increasing & PTK Mastering & 1. Deepening material. \\
\hline
\end{tabular}




\begin{tabular}{|c|c|c|c|c|c|c|}
\hline & $\begin{array}{l}\text { Action } \\
\text { Research } \\
\text { (CAR) }\end{array}$ & & & $\begin{array}{lr}\text { mastery of } \\
\text { concepts and } \\
\text { application of } \\
\text { concepts }\end{array}$ & $\begin{array}{l}\text { and can draft } \\
\text { PTK proposal }\end{array}$ & $\begin{array}{l}\text { 2. Exercising in } \\
\text { identifying problems in } \\
\text { the learning process } \\
\text { 3. Development of draft } \\
\text { PTK proposals }\end{array}$ \\
\hline \multirow[t]{2}{*}{$\mathrm{C}$} & WORKSHOP & & & & & \\
\hline & $\begin{array}{l}\text { Development } \\
\text { and learning } \\
\text { device } \\
\text { packaging }\end{array}$ & - & 20 & $\begin{array}{l}\text { Improve the } \\
\text { ability to } \\
\text { develop } \\
\text { learning tools }\end{array}$ & $\begin{array}{l}\text { Establishment } \\
\text { learning device } \\
\text { at least for } 2 \mathrm{KD} \\
/ \quad \mathrm{RPP} \text { each } \\
\text { participant in } \\
\text { accordance with } \\
\text { the 2013 } \\
\text { curriculum }\end{array}$ & $\begin{array}{l}\text { Preparation of learning } \\
\text { tools that include: } \\
\text { RPP, } \\
\text { teaching materials, } \\
\text { LKS, } \\
\text { instructional media, } \\
\text { assessment instruments. } \\
\text { Note: learning device } \\
\text { considering the balance of } \\
\text { soft skills and hard skills } \\
\text { that include attitudes, } \\
\text { knowledge, and skills. }\end{array}$ \\
\hline \multirow[t]{2}{*}{$\mathrm{D}$} & $\begin{array}{l}\text { Learning } \\
\text { Practice }\end{array}$ & & & & & \\
\hline & $\begin{array}{l}\text { Implementation } \\
\text { of learning } \\
\text { (peer teaching) }\end{array}$ & & 20 & $\begin{array}{l}\text { Increasing } \\
\text { learning ability }\end{array}$ & $\begin{array}{l}\text { Enhancing } \\
\text { learning } \\
\text { implement } \\
\text { learning to } \\
\text { perform in } \\
\text { accordance with } \\
\text { the curriculum } \\
\text { of } 2013\end{array}$ & $\begin{array}{l}\text { 1. Practice learning } \\
\text { 2. Each participant } \\
\text { performed two times } \\
@ 1 \text { JP. } \\
\text { Note: One class ( } 30 \\
\text { participants), made } 3 \\
\text { groups and executed in } \\
\text { parallel. 2nd display a } \\
\text { practice exam }\end{array}$ \\
\hline $\mathrm{E}$ & Exam & & & & & \\
\hline 1 & Write & 4 & & $\begin{array}{l}\text { Measuring } \\
\text { professional } \\
\text { competence } \\
\text { and } \\
\text { pedagogical }\end{array}$ & $\begin{array}{l}\text { Measurability } \\
\text { professional and } \\
\text { pedagogical } \\
\text { competence } \\
\text { (mastery of the } \\
\text { field of study, } \\
\text { pedagogy, } \\
\text { curriculum, } \\
2013 \text {, and the } \\
\text { professionalism } \\
\text { of teachers) }\end{array}$ & $\begin{array}{l}\text { 1. Write the National } \\
\text { Exam ( } 120 \text { minutes) in } \\
\text { the form of an objective } \\
\text { test } \\
\text { 2. Write LPTKs Exam ( } 80 \\
\text { minutes) in the form of } \\
\text { case-based description }\end{array}$ \\
\hline \multirow[t]{2}{*}{2} & Practice & & $*)$ & $\begin{array}{l}\text { Measuring the } \\
\text { ability of } \\
\text { implementing } \\
\text { learning }\end{array}$ & $\begin{array}{l}\text { Measurability } \\
\text { ability to } \\
\text { implement } \\
\text { integrated } \\
\text { learning } \\
\end{array}$ & $\begin{array}{l}\text { Exam practice in peer } \\
\text { teaching a second look }\end{array}$ \\
\hline & JP Number & 44 & 46 & & & \\
\hline
\end{tabular}

Note: 
1. The development of personality and social competence of teachers integrated in the activities PLPG

2 . $^{*}$ It is integrated in the D

The final exam must be able to ensure that the candidate has met the standards of competence as defined in the Act No. 14 of 2005 on Teachers and Lecturers and Ministerial Regulation No. 16 Year 2007 on Academic Qualification Standards and Teacher Competency.

Referring to the entire range of the recorded material in the curriculum PLPG 2013 of SMP, obtained an assumption that the curriculum be able to make a professional teacher as long as the teachers follow these materials into a variety of activities that professionalism continuum. In this case the teachers who had completed follow PLPG order to participate in various activities that are the subject of deliberation teachers (MGMP) and also in the activities of teachers in the activities of the working group (KKG) regularly and continuously. This needs to be done to ensure that all materials obtained in PLPG not vain but still grow and develop in the maintenance frame every teacher's professionalism.

PLPG is not a panacea that will make immediately become professional teachers. PLPG is a tool that allows teachers to understand what the main task so that it can perform the function as educators, chaser, mentor, and coach. Therefore, after following PLPG, teachers are expected to develop themselves through a variety of activities that can improve herself as a professional teacher. This needs to be done by each teacher to ensure continuity professionalism.

Professional teachers can be seen from the ability to perform the task as well as possible, including the task of education and teacher training, and also tasks that demonstrate the credibility of his personality in front of the public and his colleagues. If the community and colleagues acknowledge the existence and the existence of the teacher, should be assumed that the teacher has been able to follow up the results PLPG.

However, the results are not permanent nature PLPG it, because what is obtained in PLPG just the beginning of science, knowledge, and attitudes to establish teacher's professionalism performed continuously and can accept the changes for what happened so that change is something that is understood.

\section{CONCLUSION}

Success in achieving the goals of education is largely determined by the success of teacher professionalism in performing the task. The success means one of them is of course determined by the professionalism of teacher education curriculum. In this regard, what is given to teachers through curriculum professionalism in teacher education and professional training is something that is quite crucial.

Through education and training curriculum the teaching profession (PLPG), seems at deems sufficient to give to the teacher when the certification process is underway. Curriculum is in stacking in PLPG, of course, not everything for creating professional teachers. PLPG curriculum was collated as an instrument to introduce to teachers how to deliver teaching materials perfectly with attention to the condition of the learner as object and subject of study.

Through the PLPG curriculum, teachers introduced to the nature or kind of teaching materials. The teacher introduced how to distinguish approaches, strategies, methods, techniques, tactics, models, and even instructional design. This all will allow every teacher who participated in PLPG familiar with a variety of learning approaches to teaching materials submitted will run effectively.

\section{REFERENCES}


Abduhzen, M. (2014). Kompas, Sabtu, 13 September. Page 6. "Pemimpin yang Peduli Pendidikan."

Aly. H.N. \& M. (2000). Watak Pendidikan Islam, Jakarta: Friska Agung Insani.

Amini. (2013). Profesi Keguruan, Medan: Perdana Publishing.

Jalaluddin. (2002). Teologi Pendidikan Islam, Jakarta: Raja Grafindo Persada.

Kemendikbud. (2013). Buku 1 Pedoman Penetapan Peserta, Jakarta: Kementerian Pendidikan dan Kebudayaan, Badan Pengembangan Sumber Daya Manusia Pendidikan dan Penjaminan Mutu Pendidikan.

Kementerian Agama Direktorat Jenderal Pendidikan Agama Islam, Direktorat Pendidikan Agama Islam Pada Sekolah, Modul Pengembangan Pendidikan Agama Islam Pada Sekolah Tahun 2010.

Muhaimin. (2003). Arah Baru Pengembangan Pendidikan Islam (Pemberdayaan, Pengembangan Kurikulum hingga Redefinisi Islamisasi Pengetahuan), Bandung, Nuansa.

Undang-Undang Republik Indonesia Nomor 14 Tahun 2005 Tentang Guru dan Dosen 